ORIGINAL ARTICLE / ARTIGO ORIGINAL

\title{
Analysis of care given to patients with hypertension in Belo Horizonte, according to telephone survey
}

\author{
Análise do cuidado dispensado a portadores de hipertensão arterial em \\ Belo Horizonte, segundo inquérito telefônico
}

\author{
Tatiana Dias Paulucci', Gustavo Velasquez-Melendez', Regina Ivata Tomie Bernal", \\ Francisco Félix Lana', Deborah Carvalho Malta',,II
}

\begin{abstract}
Objective: To examine the care given to patients with hypertension in the Brazilian public and private health services in the population of Belo Horizonte, Minas Gerais. Methods: Telephone interviews were conducted in a sample of hypertensive adults in the year 2009, in Belo Horizonte ( $n=100)$. We compared the care provided to hypertensive users of the Unified Health System (SUS) and of the Supplementary Health (SS), using the $\chi^{2}$ test or Fisher's exact test. The prevalence ratio was calculated by the Poisson regression model, adjusted for the variables age, education and skin color. Results: In the descriptive analysis, hypertensive users of private health plans had a higher frequency of physician referral and greater blood pressure control. Unified Health System users were the ones who participated in health promotion groups the most. The acquisition of antihypertensive medications by beneficiaries of private health insurance was more frequent in private pharmacies, and in Health Centers among users of the Unified Health System. The differences disappeared when adjusting the variables for age, race and education. There was no difference regarding the guidance received for a change of habits, or regarding the incorporation of these healthy practices promotion by hypertensive patients. Conclusion: A healthier diet, the practice of physical activity, and the non-use of alcohol and tobacco have been incorporated by hypertensive patients, whether owning private health insurance or not. Promotion practices, proper use of medication a clinical follow-up are important for the control of blood pressure levels.

Keywords: Hypertension. Unified Health System. Health surveys. Chronic disease. Surveillance system based on telephone interviews.
\end{abstract}

\footnotetext{
'Nursing School. Public Health Maternal-Child Nursing Department. Universidade Federal de Minas Gerais - Belo Horizonte (MG), Brazil. "Center for Epidemiological Research in Nutrition and Health, Universidade de São Paulo - São Paulo (SP), Brazil.

"'Health Surveillance Secretariat, Ministry of Health - Brasília (DF), Brazil.

Corresponding author: Gustavo Velasquez-Melendez. Universidade Federal de Minas Gerais. Escola de Enfermagem. Avenida Alfredo Balena, 190, CEP: 30130-100, Belo Horizonte, MG, Brasil. E-mail:guveme@ufmg.br

Conflict of interests: nothing to declare - Financing source: Ministry of Health.
} 
RESUMO: Objetivo: Analisar o cuidado dispensado aos hipertensos na população de Belo Horizonte, segundo posse ou não de plano de saúde privado. Métodos: Foram realizadas entrevistas telefônicas em amostra de adultos hipertensos no ano de 2009 em Belo Horizonte $(n=100)$. O cuidado prestado aos hipertensos usuários do Sistema Único de Saúde (SUS) e Saúde Suplementar (SS) foram comparados usando os testes de $\chi^{2}$ de Pearson ou exato de Fisher. Foi calculada a razão de prevalência (RP), estimada pelo modelo de regressão de Poisson, ajustada segundo idade, escolaridade e cor da pele. Resultados: Na análise descritiva, os hipertensos usuários de planos de saúde privado tiveram maior frequência de médico de referência e maior controle de pressão arterial. Os usuários do SUS foram os que mais frequentaram grupos operativos de promoção à saúde. A aquisição de medicamentos antihipertensivos pelos beneficiários da SS foi mais frequente nas farmácias privadas, e, entre os usuários do SUS, nos Centros de Saúde. As diferenças desapareceram ao se ajustarem as variáveis por idade, cor da pele e escolaridade. Não houve diferença quanto às orientações recebidas de mudanças de hábitos, e nem em relação à incorporação destas práticas saudáveis de promoção pelos hipertensos. Conclusão: Práticas de alimentação saudável, atividade física e o não uso de álcool e tabaco têm sido incorporados pelos hipertensos, independentes da posse ou não de planos de saúde. As práticas de promoção, uso correto de medicação e acompanhamento clínico são importantes para o controle dos níveis pressóricos.

Palavras-chave: Hipertensão. Sistema Único de Saúde. Inquéritos epidemiológicos. Doença crônica. Sistemas de vigilância por inquérito telefônico.

\section{INTRODUCTION}

The Brazilian population has experienced significant changes in its demographic profile, with declining fecundity and birth rates, increments in life expectancy, and growing elderly population. Scenarios of epidemiological transition have been observed, as well as the proportional reduction of infectious-contagious diseases and increasing chronic noncommunicable diseases, besides nutritional transition, with declining malnourishment and increasing excessive weight and obesity ${ }^{1,2}$.

The Chronic Non-Communicable Diseases (CNCD) are the main cause of mortality and premature disability in most countries of the world, including Brazil, corresponding to $63 \%$ of the causes of death in the world and about 36 million annual deaths ${ }^{2,3}$.

Among the CNCDs, the ones that stand out due to their magnitude are cardiovascular diseases (arterial hypertension, infarction, stroke), chronic respiratory diseases, cancer and diabetes mellitus ${ }^{4}$. Studies point out that arterial hypertension $(\mathrm{AH})$ affects about $22 \%$ of the Brazilian population aged more than 20 years old, and it could be responsible for $80 \%$ of the stroke cases and $60 \%$ of cases of acute myocardial infarction ${ }^{5}$.

Arterial hypertension has generated major impact on morbimortality in Brazil and in the world. Data from the World Health Organization (WHO) indicate the existence of 
600 million people affected by systemic arterial hypertension (SAH), and about 7.1 million annual deaths, which correspond to $13 \%$ of global mortality ${ }^{3}$.

Studies show that the quality of provided care requires follow-up, full approach, continuous use of medications, adoption of healthy lifestyles, thus articulating actions of health promotion, prevention, diagnosis and care ${ }^{6,7}$. However, this quality can range according to the access and nature of services (public or private), the existence of a protection network, qualification and availability of professionals, waiting time, among others ${ }^{8-10}$. In the country, Supplementary Health covers about $25 \%$ of the population, especially in Belo Horizonte, in Minas Gerais, where coverage reaches $51 \%$, with growing tendency in the past years ${ }^{11-13}$.

It is relevant to know how the care provided to hypertensive patients has taken place in the different health system services, be them public or private. The quality of care provided to the user is essential to obtain better results, such as AH control, the reduction of morbidities and more severe outcomes ${ }^{6,7}$.

The objective of this study was to analyze the care provided to hypertensive patients in the population aged 18 years old or more, in the city of Belo Horizonte, according to the financing modality (Supplementary Health and Unified Health System).

\section{METHODS}

This is an epidemiological, descriptive, cross-sectional, population-based study conducted with the use of a subsample from the Telephone-Based Surveillance of Risk and Protective Factors for Chronic Diseases (VIGITEL) ${ }^{14}$.

The system establishes a sample of about two thousand individuals, aged 18 years old or more, in each city, so that it is possible to estimate the frequency of indicators investigated in the adult population with a $95 \%$ confidence interval and maximum sampling error of about two percentage points, The sampling procedures used by VIGITEL aim at obtaining, in each of the 26 Brazilian State capitals and the Federal District, probability samples of the population of adults living in households with at least one landline ${ }^{14}$.

For this study, data bases referring to the VIGITEL samples of 2008, in the city of Belo Horizonte, were used. Participants who declared being hypertensive or diabetic composed the eligible population.

The VIGITEL system registered, in Belo Horizonte, in 2008, 2016 interviews distributed in 17 replicas or subsamples, containing about 200 landlines each. Out of these, the last five replicas were selected for re-interviews (replicas 13 to 17). In these five replicas, in 2008 , 545 interviews were conducted, because each replica had about $25 \%$ of non-eligible lines for the study, such as commercial lines, lines that did not answer after six attempts made in different days and times, including Saturdays, Sundays and night-periods, and that probably correspond to a closed household. A new interview was conducted in 2009, and individuals who had self-reported arterial hypertension in 2008 and confirmed the diagnosis in 2009 were interviewed again with a structured questionnaire about care. It was not 
possible to interview 38 individuals, who either refused to participate or confirmed the arterial hypertension diagnosis in the re-interview. Therefore, 100 hypertensive individuals participated in the re-interview.

The hypertensive patients of replicas 1 to 12 from 2008, composing group 1 ( $n=567$ ), were compared to hypertensive students in the studied sample (replicas 13 to 17), composing group $2(\mathrm{n}=100)$, with the objective of determining if these groups were similar, or if the population of re-interviewed hypertensive patients in 2009 represents the population of hypertensive patients from Belo Horizonte, in 2008. The Kolgomorov-Smirnov (KS) test was used, which is adequate for discrete and continuous variables. The test verified the maximum absolute difference between two functions of accumulate functions. The following variables were assessed by means of the KS test: age, BMI, sex and schooling years. The $\chi^{2}$ test was used to compare the variable $\operatorname{sex}^{15}$.

The sample of hypertensive patients studied in 2009 did not undergo the post-stratification procedures used in VIGITEL, because the sample does not aim at representing the general population, but the population of hypertensive people in Belo Horizonte, in which the elderly are prevalent.

The following distributions were obtained for the studied sample:

- Sociodemographic characteristics: sex, age, schooling, ethnicity/color;

- Body mass index (BMI);

- Characteristics of the provided are: time of diagnosis, existence of a medical caretaker, visit to health services;

- Recommendations received from health professionals during appointments: use of anti-hypertensive medications, last blood pressure measurement;

- Health promotion actions indicated by professionals: participation in groups of health promotion and arterial hypertension control, orientations received from health professional about: changing dietary habits, reducing salt consumption, restriction to alcohol and tobacco;

- Actions of health promotion adopted by hypertensive patients: diet, salt reduction, physical activity, restriction to alcohol and smoking, use of medications.

In order to test the differences in the case of categorical variables between groups, the $\chi^{2}$ test or the Fisher exact test with a $5 \%$ significance level were used. Statistical processing was conducted with the Statistical Software for Professionals (STATA), version 9.0, and the Statistical Package for the Social Sciences (SPSS), version 17.0.

In order to analyze the independently significant differences in the care provided to hypertensive patients according to the financing modality (Supplementary Health and Unified Health System), a multivariate adjustment of the results was made with the calculation of the Prevalence Ratio (PR), as well as its respective confidence intervals (95\% CI), estimated by the Poisson regression and adjusted by age, schooling, sex and skin color.

Since the interviews were conducted by telephone, the informed consent form was replaced by the verbal consent, obtained at the time interviewees were contacted by telephone. 
The project to implement VIGITEL was approved by the Human Research Ethics Committee of the Ministry of Health and in the Research Ethics Committee of Universidade Federal de Minas Gerais, report n. 552/08.

\section{RESULTS}

The subsample was composed of 114 participants and $17(15 \%)$ reported being diabetic and hypertensive, $14(12 \%)$ declared being diabetic, and $84(73 \%)$ declared being hypertensive. Diabetic people were excluded from the analysis $(n=14)$, resulting in a final sample of 100 hypertensive patients.

Figure 1 shows the results of the adhesion test comparing both groups of hypertensive patients: group 1 (replicas 1 to 12) and group 2 (replicas 13 to 17), as to sociodemographic characteristics (age, schooling, sex) and BMI. The analysis shows that hypertensive adults of both samples are similar, so there is no difference between the proportions of the compared variables $(p>0.05)$.

A - schooling $\left(\mathrm{KS}^{*} ; \mathrm{p}=0.497\right)$

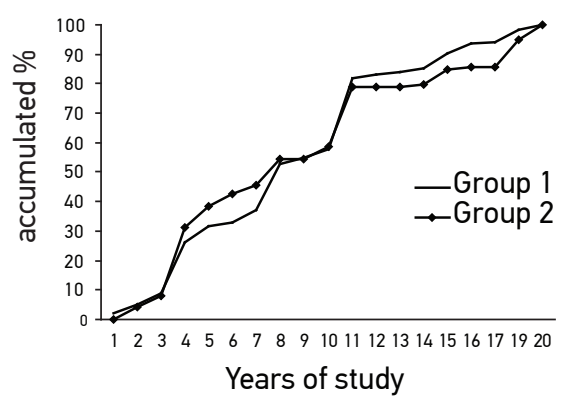

$C-\operatorname{sex}\left(\chi^{2} ; p=0.456\right)$

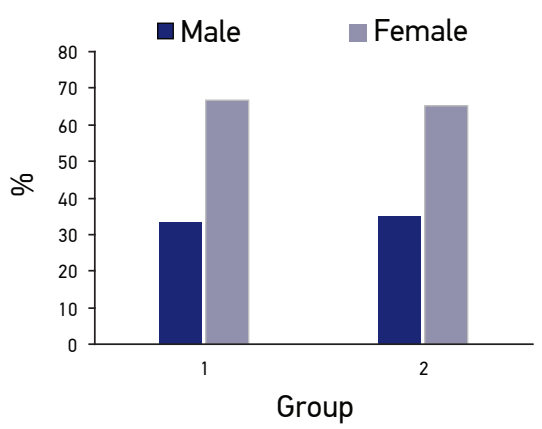

$B-B M I\left(K S^{*} ; p=0.314\right)$

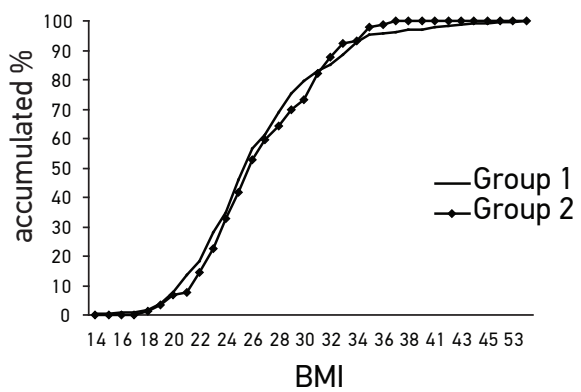

$\mathrm{D}-$ age $\left(\mathrm{KS}^{*} ; \mathrm{p}=0.093\right)$

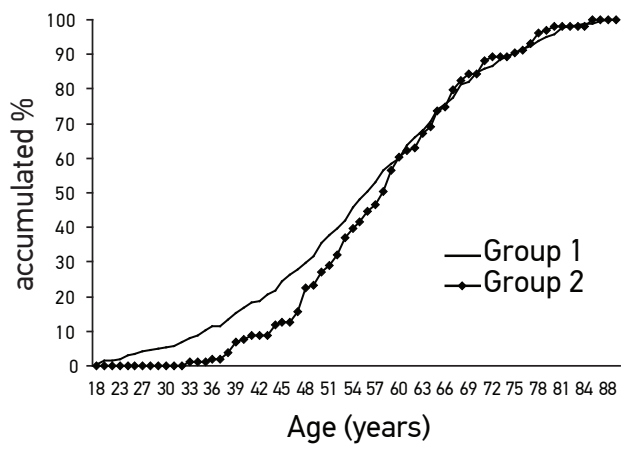

${ }^{*} \mathrm{KS}$ : Kolmogorov-Smirnov; BMI: body mass index.

Figure 1. Comparison of the cumulative distribution of sociodemographic variables and body mass index in hypertensive people in samples A and B, Belo Horizonte, 2008, 2009. 
Table 1 presents the sociodemographic characteristics and the BMI of the studied population according to the public or private financing modality of the health plan. It is possible to observe that female participants were prevalent (65\%), aged more than 55 years old (60\%), with zero to eight schooling years $(54.2 \%)$, with non-white skin color $(60 \%)$ and $\mathrm{BMI} \geq 25 \mathrm{~kg} / \mathrm{m}^{2}(69.8 \%)$. By comparing the hypertensive patients according to the fact of owning a health insurance plan or not, $58 \%$ were users of the Supplementary Health (SH), and $42 \%$ were users of SUS. It was possible to observe significant differences between these two groups (users of SUS and beneficiaries of $\mathrm{SH}$ ) as to schooling $(\mathrm{p}<0.001)$, ethnicity/skin color $(\mathrm{p}=0.005)$ and age group $(\mathrm{p}=0.024)$. Among users who use SUS exclusively, individuals with lower schooling, from zero to eight schooling years $(82.2 \%)$; non-white $(76.2 \%)$ and people aged between 35 to 54 years old $(73.8 \%)$ were prevalent.

Table 1. Comparison of sociodemographic characteristics and BMI in the study population, according to financing modality (Supplementary Health and Unified Health System). Belo Horizonte, 2009.

\begin{tabular}{|c|c|c|c|c|}
\hline Variables & $\begin{array}{l}\text { Total } \\
\text { n (\%) }\end{array}$ & $\begin{array}{c}\text { Supplementary } \\
\text { Health } \\
\mathrm{n}(\%)\end{array}$ & $\begin{array}{c}\text { Unified Health } \\
\text { System } \\
\text { n (\%) }\end{array}$ & p-value* \\
\hline \multicolumn{5}{|l|}{ Sex } \\
\hline Male & $35(35.0)$ & $23(39.7)$ & $12(28.6)$ & 0.251 \\
\hline Female & $65(65.0)$ & $35(60.3)$ & $30(71.4)$ & \\
\hline \multicolumn{5}{|l|}{ Color } \\
\hline White & $40(40.0)$ & $30(51.7)$ & $10(23.8)$ & 0.005 \\
\hline Non-White & $60(60.0)$ & $28(48.3)$ & $32(76.2)$ & \\
\hline \multicolumn{5}{|l|}{ Schooling } \\
\hline 0 to 8 years old & $52(54.2)$ & $20(35.1)$ & $32(82.2)$ & $<0.001$ \\
\hline 9 to 11 years old & $24(25)$ & $19(33.3)$ & $5(12.8)$ & \\
\hline Older than 11 years old & $20(20.8)$ & $18(31.6)$ & $2(5.1)$ & \\
\hline \multicolumn{5}{|l|}{ Age } \\
\hline 18 to 34 years old & $1(1.0)$ & - & $1(2.4)$ & 0.024 \\
\hline 35 to 44 years old & $10(10.0)$ & $6(10.3)$ & $4(9.5)$ & \\
\hline 45 to 54 years old & $29(29.0)$ & $14(24.1)$ & 15 (35.7) & \\
\hline 55 to 64 years old & $30(30.0)$ & $14(24.1)$ & $16(38.1)$ & \\
\hline$>64$ years old & $30(30.0)$ & $24(41.4)$ & $6(14.3)$ & \\
\hline \multicolumn{5}{|l|}{$\mathrm{BMI}$} \\
\hline Malnourished or eutrophic & $26(30.2)$ & $18(34.0)$ & $8(24.2)$ & 0.340 \\
\hline Excessive weight & $60(69.8)$ & $35(66.6)$ & $25(75.8)$ & \\
\hline
\end{tabular}

BMI: Body mass index.

${ }^{*} \chi^{2}$ test or Fisher's exact. 
Among beneficiaries of Supplementary Health, it was possible to observe higher schooling (31.6\%), more white people (51.7\%) and people aged more than 64 years old $(41.4 \%)$.

Table 2 compares the care provided to the hypertensive population ( $\mathrm{SH}$ versus SUS). It was observed that hypertensive beneficiaries of $\mathrm{SH}$ reported having a reference doctor more often (84.5\%) when compared to users of SUS (61.9\%), more success in the control of systolic arterial hypertension (76.6\% versus $50 \%)$ and also in the control of diastolic arterial pressure $(70.2 \%$ versus $45.2 \%)$. However, the prevalence ratios

Table 2. Comparison of the care provided to hypertensive population according to financing modality (Supplementary Health and Unified Health System). Belo Horizonte-2009.

\begin{tabular}{|c|c|c|c|c|c|}
\hline \multirow[t]{2}{*}{ Variables } & Total & $\begin{array}{c}\text { Supplementary } \\
\text { Health }\end{array}$ & $\begin{array}{c}\text { Unified Health } \\
\text { System }\end{array}$ & \multirow[t]{2}{*}{ p-value* } & \multirow[t]{2}{*}{ PR } \\
\hline & n (\%) & n (\%) & n (\%) & & \\
\hline \multicolumn{6}{|l|}{ Time of diagnosis of $\mathrm{AH}$} \\
\hline 1 to 3 years & $15(15.8)$ & $7(12.5)$ & $8(20.5)$ & 0.146 & \\
\hline$>3$ years & $80(84.2)$ & $49(87.5)$ & $31(79.5)$ & & \\
\hline \multicolumn{6}{|l|}{ Medical reference } \\
\hline Yes & $75(75)$ & $49(84.5)$ & $26(61.9)$ & 0.010 & 1.20 \\
\hline No & $25(25)$ & $9(15.5)$ & $16(38.1)$ & & $(0.69-2.08)$ \\
\hline \multicolumn{6}{|l|}{ Visit to health care } \\
\hline Yes & $74(74.7)$ & $45(77.6)$ & $29(70.7)$ & 0.439 & - \\
\hline No & $25(25.3)$ & $13(22.4)$ & $12(29.3)$ & & \\
\hline \multicolumn{6}{|c|}{ Time of last medical appointment } \\
\hline Less than 6 months & $69(94.5)$ & $41(93.2)$ & $28(96.6)$ & 0.477 & - \\
\hline 7 months or more & $4(5.5)$ & $3(6.8)$ & $1(3.4)$ & & \\
\hline \multicolumn{6}{|c|}{ Recommendation for anti-hypertensive } \\
\hline Yes & $99(99.0)$ & $58(100.0)$ & $41(97.6)$ & - & - \\
\hline No & $1(1.0)$ & - & $1(2.4)$ & & \\
\hline \multicolumn{6}{|c|}{ Last BP measurement in the past month } \\
\hline Yes & $70(70.7)$ & $38(65.5)$ & $32(78.0)$ & 0.088 & \\
\hline No & $29(29.3)$ & $20(34.5)$ & $9(22.0)$ & & \\
\hline \multicolumn{6}{|l|}{ Normal/controlled SBP } \\
\hline Yes & $52(65.82)$ & $36(76.6)$ & $16(50.0)$ & 0.014 & 1.49 \\
\hline No & $27(34.18)$ & $11(23.4)$ & $16(50.0)$ & & $(0.77-2.87)$ \\
\hline \multicolumn{6}{|l|}{ Normal/controlled DBP } \\
\hline Yes & $47(60.25)$ & $33(70.2)$ & $14(45.2)$ & 0.027 & 1.61 \\
\hline No & $31(39.74)$ & $14(29.8)$ & $17(54.8)$ & & $(0.82-3.15)$ \\
\hline
\end{tabular}

AH: arterial hypertension; BP: Blood pressure; SBP: Systolic blood pressure; DBP: Diastolic pressure; * $\chi^{2}$ or Fisher's exact test of Fisher Pearson; PR: prevalence ratio adjusted for age, education, sex and skin color; - statistical test not performed. 
adjusted by age, sex and schooling show that prevalence rates were similar. Besides, there were no differences as to the time of diagnosis, attendance at health services, duration of last doctor's appointment, orientation to use anti-hypertensive medications, time of the last BP measurement, according to SUS or SH.

Table 3 shows the comparison of health promotion actions provided to participants, according to financing modality (SH versus SUS). The participation in an operative group for AH control, orientation to reduce salt and the consumption of alcohol, as well as the practice of physical activity and orientation about dietary habits, except for advisement about smoking, was always more prevalent in the SH group. However, the prevalence ratio adjusted by age, sex and schooling shows similar prevalence for all of the orientations.

Table 3. Comparison of health promotion strategies offered to hypertensive patients, according to financing modality (Supplementary Health and Unified Health System). Belo Horizonte, 2009.

\begin{tabular}{|c|c|c|c|c|c|}
\hline \multirow[t]{2}{*}{ Variables } & Total & \begin{tabular}{|c|} 
Supplementary \\
Health
\end{tabular} & \begin{tabular}{|c|}
$\begin{array}{c}\text { Unified Health } \\
\text { System }\end{array}$ \\
\end{tabular} & \multirow[t]{2}{*}{ p-value* } & \multirow[t]{2}{*}{ PR } \\
\hline & n (\%) & $\mathrm{n}(\%)$ & $\mathrm{n}(\%)$ & & \\
\hline \multicolumn{6}{|c|}{ Educational group/activity } \\
\hline Yes & $25(25.0)$ & $10(17.2)$ & $15(35.7)$ & 0.035 & 1.01 \\
\hline No & $75(75.0)$ & $48(82.8)$ & $27(64.3)$ & & $(0.40-2.56)$ \\
\hline \multicolumn{6}{|c|}{ Orientation as to salt consumption } \\
\hline Yes & $93(93.0)$ & 55 (94.8) & $38(90.5)$ & 0.324 & - \\
\hline No & $7(7.0)$ & $3(5.2)$ & $4(9.5)$ & & \\
\hline \multicolumn{6}{|c|}{ Orientation as to alcohol consumption } \\
\hline Yes & $58(89.3)$ & $33(94.3)$ & $25(83.3)$ & 0.154 & - \\
\hline No & $7(10.7)$ & $2(5.7)$ & $5(16.7)$ & & \\
\hline \multicolumn{6}{|c|}{ Orientation as to smoking } \\
\hline Yes & $7(8.0)$ & $4(7.4)$ & $3(8.8)$ & & \\
\hline No & $81(92.0)$ & $50(92.6)$ & $31(91.2)$ & 0.463 & - \\
\hline \multicolumn{6}{|c|}{ Orientation as to physical activity } \\
\hline Yes & $94(94.0)$ & 55 (94.8) & $39(92.9)$ & 0.694 & - \\
\hline No & $6(6.0)$ & $3(5.2)$ & $3(7.1)$ & & \\
\hline \multicolumn{6}{|c|}{ Orientation as to dietary habits } \\
\hline Yes & $81(83.5)$ & 45 (81.9) & $36(85.7)$ & 0.784 & - \\
\hline No & $16(16.5)$ & $10(18.2)$ & $6(14.3)$ & & \\
\hline
\end{tabular}

*Pearson's $\chi^{2}$ or Fisher's exact test; PR: prevalence ratio adjusted for age, sex, education and skin color. 
Table 4 shows that habits / orientations incorporated by hypertensive patients were: report of having reduced salt in $92 \%$, the adoption of a diet in $36 \%$, the incorporation of regular physical activity in $51 \%$, the regular use of anti-hypertensive medication in $95 \%$, and the use of anti-hypertensive medication only when BP was high in $6 \%$. In the comparison between changes of practices according to financing modality (SH versus SUS), the prevalence ratio adjusted by age and schooling shows similar prevalence rates between these groups.

Table 4. Changes in practices (salt, diet, physical activity, medications) and medicine acquisition, among hypertensive patients, according with the financing modality (Supplementary Health and Unified Health System). Belo Horizonte, 2009.

\begin{tabular}{|c|c|c|c|c|c|}
\hline \multirow{2}{*}{ Variables } & Total & $\begin{array}{c}\text { Supplementary } \\
\text { Health }\end{array}$ & $\begin{array}{c}\text { Unified Health } \\
\text { System }\end{array}$ & \multirow[t]{2}{*}{ p-value* } & \multirow[t]{2}{*}{ PR } \\
\hline & $\mathrm{n}(\%)$ & $\mathrm{n}(\%)$ & $\mathrm{n}(\%)$ & & \\
\hline \multicolumn{6}{|c|}{ Reduction in salt intake } \\
\hline Yes & $92(92.0)$ & $54(93.1)$ & $38(90.5)$ & 0.633 & \\
\hline No & $8(8.0)$ & $4(6.9)$ & $4(9.5)$ & & \\
\hline \multicolumn{6}{|c|}{ Diet to lose/maintain weight } \\
\hline Yes & $36(36.0)$ & $19(32.8)$ & $17(40.5)$ & 0.427 & \\
\hline No & $64(64.0)$ & $39(67.2)$ & $25(59.5)$ & & \\
\hline \multicolumn{6}{|c|}{ Regular practice of physical activity } \\
\hline Yes & $51(51.0)$ & $31(53.4)$ & $20(47.6)$ & 0.565 & \\
\hline No & $49(49.0)$ & $27(46.6)$ & $22(52.4)$ & & \\
\hline \multicolumn{6}{|c|}{ Regular use of medication } \\
\hline Yes & $95(95.0)$ & $56(96.6)$ & $39(92.9)$ & 0.647 & \\
\hline No & $5(5.0)$ & $2(3.4)$ & $3(7.1)$ & & \\
\hline \multicolumn{6}{|c|}{ Use of medication with high BP } \\
\hline Yes & $6(6.0)$ & $2(3.4)$ & $4(9.5)$ & 0.235 & \\
\hline No & $94(94.0)$ & $56(96.6)$ & $38(90.5)$ & & \\
\hline \multicolumn{6}{|c|}{ Acquisition of medications } \\
\hline \multirow[t]{2}{*}{ Health Center } & $38(38.0)$ & $10(17.2)$ & $28(66.7)$ & & 0.59 \\
\hline & & & & & $(0.22-1.11)$ \\
\hline \multirow[t]{2}{*}{ Popular drugstore } & $13(13.0)$ & $9(15.5)$ & $4(9.5)$ & $<0.001$ & 1.24 \\
\hline & & & & & $(0.36-4.30)$ \\
\hline \multirow[t]{2}{*}{ Private drugstore } & $49(49.0)$ & $39(67.2)$ & $10(23.8)$ & & 1.98 \\
\hline & & & & & $(0.95-4.13)$ \\
\hline
\end{tabular}

* Pearson's $\chi^{2}$ or Fisher's exact test; PR: prevalence ratio adjusted for age, education, sex and skin color; BP: blood pressure. 


\section{DISCUSSION}

Some sociodemographic differences were found in this study between beneficiaries of SH versus SUS, and beneficiaries of SH presented higher schooling, were older and white. In the analyses adjusted by age, skin color, sex and schooling, no differences were observed regarding systolic (SBP) and diastolic blood pressure (DBP) control, reference doctor (caretaker), orientations about changing habits, incorporation of healthy health promotion actions and prevention of hypertension and acquisition of antihypertensive medications. However, it is worth to mention that, despite the significant differences shown between groups ( $\mathrm{SH}$ versus SUS) by means of significant bivariate associations, they were not maintained in the multivariate models. Since the objective was not the one of establishing causality relations, the significant variables in bivariate models could potentially be faced as group markers. For example, a higher percentage of medical reference, blood pressure control and acquisition of medications from the private network was observed in the SH group, and more participation and acquisition of medications in the health center, in the SUS group.

Another result pointed out by this study was that owning a health insurance plan in Belo Horizonte corresponded to almost double the national average (25\%). Similar data were registered by the Record of the National Agency of Supplementary Health ${ }^{13}$ and by the Brazilian National Household Survey ${ }^{11}$. On the other hand, beneficiaries of $\mathrm{SH}$ presented higher schooling.

The fact of owning health plans in Brazil reveals social inequalities concerning the access and the use of health services. Owners of health plans in general are individuals with high family income, formal jobs, high schooling, differences of skin color and who assess their own health status as very good and good, besides having more access to health services ${ }^{11,12,16-18}$.

From the total number of people with hypertension who were re-interviewed, $65 \%$ were female, which can be attributed to the fact that it was a self-reported declaration, and this is compatible with the fact that women look for health services more often and, consequently, there are more chances of making a medical diagnosis in this group ${ }^{19,20}$.

Arterial hypertension tends to be more common among the elderly, and the study corroborates data from literature, thus ensuring the increasing frequency of $\mathrm{SAH}$ related to age. Individuals aged more than 55 years old accumulated $60 \%$ of the SAH frequency ${ }^{21}$.

Elderly hypertensive patients are prevalent, when stratified by owning a health insurance plan, hypertensive people aged more than 64 years old were three times more frequent than users of SUS. This characteristic is different from national data, which point out that beneficiaries of $\mathrm{SH}$ are mostly at productive age, especially between 30 and 59 years old ${ }^{11,13}$, which is justified by the prevalence of collective plans $(80 \%)$, paid by the employers ${ }^{11}$. The prevalence of elderly people in health plan operators in Belo 
Horizonte, in relation to the country, had already been identified in a comparative study between seven health insurance operators (self-management, insurance companies, collective medicine and cooperatives $)^{22}$. The authors attributed the finding to the fact that the local operator that is prevalent in the market of Belo Horizonte commercializes individual plans, which have been financed by the families, due to the higher risk of using the plan at this age group or to the more frequent search for health insurance plans by elderly people ${ }^{22}$.

More than two thirds of hypertensive people presented with excessive weight, body mass index $\geq 25$, which is compatible with national literature ${ }^{20}$. It is estimated that 20 to $30 \%$ of the prevalence of hypertension can be explained by excessive weight ${ }^{23}$.

Time of hypertension diagnosis was superior to three years. According to Passos et $\mathrm{al}^{24}$, examinations to detect high levels of blood pressure are more accessible to the population by SUS, which can explain the fact that the diagnosis was made for before.

Health promotion activities, such as participation in groups, were reported by only one quarter of hypertensive participants, which may reflect the little priority given to this practice both for users of insurance plans and users of SUS. The little participation of hypertensive patients in operative groups is a matter of concern, since such an activity is important to control SAH and the consequent prevention of problems related to it. The groups may enable individuals to coproduce the educational process, where they will be both object of the work of educational agents and subjects of their own education, which allows the construction of care focused on the needs of social groups, with an emancipatory educational dimension ${ }^{25,26}$.

For Alves ${ }^{27}$, the integrality of care can be expressed in educational activities for health during ambulatory care, and the meeting of the hypertensive group contributes in this process. Studies show important reduction in blood pressure with the implement of physical activities, reduced salt consumption and a healthy $\operatorname{diet}^{28,29}$.

Ribeiro et al. ${ }^{18}$ observed that the regular attendance of hypertensive patients to doctors' appointments presented a positive correlation with adhesion to treatment. In this study, about two thirds attended appointments regularly, which may justify good results, including the adhesion to health promotion practices. The recommendation of not smoking and not drinking were not properly informed to patients by their doctors. The use of medications was also recommended by professional, and tobacco was an important factor associated with $\mathrm{AH}^{23}$.

There was a difference as to the place of acquiring the medications with relation to owning a health insurance plan or not. Most users of SUS looks for care more often in Health Centers, while the ones with insurance plans usually go to private drugstores. A study points out that more than half of the participants had no difficulties to obtain medications to control BP, and that the free supply of medications for anti-hypertensive therapy, in the health network, was been relevant for treatment follow-up ${ }^{18}$. In a study about treatment adhesion, it was observed that most individuals (91.1\%) reported 
that the cost of medication was not a reason to abandon the treatment, and, out of there, $82.2 \%$ acquire these medicines in the drugstore of the basic health unit ${ }^{30}$. The availability of free medicines for hypertension and diabetes in the program "Aqui tem Farmácia Popular" (in English, "the Popular Drugstore Is Here), from the Ministry of Health, tends to amplify the access to medications ${ }^{2}$.

Most hypertensive patients had normal pressure values below 140/90 mmHg. It is important to control it, aiming at preventing ischemic heart diseases and cerebrovascular diseases ${ }^{31}$. Small reductions, both in SBP and DBP, have a major impact on the reduction of cardiovascular mortality ${ }^{21}$.

Among the limitations of the study, the fact that the sample was restricted to those with a landline stands out. However, the coverage of landlines in Belo Horizonte is higher than the average of the country, which allows the reduction of a possible selection bias ${ }^{32}$. Besides, studies comparing the results of VIGITEL with household surveys showed similar results, indicating the adequate external validity of the system ${ }^{33}$. Therefore, characteristics such as sex, age, schooling and age group of hypertensive patients may present differences with relation to the general population. Another limitation refers to the use of the variable self-reported hypertension, depending on the access to medical diagnosis. Studies that have assessed these data, however, indicate advantages in its use because it is easy and low-cost ${ }^{34}$. Besides, the small sample makes analysis more difficult, especially to identify specific associations. Most variables presented differences in descriptive analyses, but disappeared after the adjustment, partly due to the small sample size.

We conclude that it is important to incorporate practices of health promotion in the care provided to the hypertensive patient, which has been observed in the practices of users of SUS and Health Plans. Health professionals have been recomending practices of healthy diet, physical activity, non-use of alcohol and tobacco, and this has been incorporated by users. Practices of promotion, proper use of medication and clinical follow-up are important to control pressure levels. We recommend that this study be replied with a larger sample, aiming at confirming the results.

\section{REFERENCES}

1. Schmidt MI, Duncan BB, Azevedo e Silva G, Menezes AM, Monteiro CA, Barreto SM et al. Chronic non-communicable diseases in Brazil: burden and current challenges. The Lancet 2011; 377(9781): 1949-61.
Brasil. Secretaria de Vigilância em Saúde. Departamento de Análise de Situação de Saúde. Plano de ações estratégicas para o enfrentamento das doenças crônicas não transmissíveis (DCNT) no Brasil 2011-2022. Ministério da Saúde; 2011 p. 148. 
3. World Health Organization. Global status report on noncommunicable diseases 2010. Geneva: WHO; 2011

4. World Health Organization. Integrated management of cardiovascular risk: report of a WHO meeting. Geneva; 2002.

5. Barros MB, César CLG, Carandina L, Goldbaum M, et al. As dimensões da saúde: inquérito populacional em Campinas. Cad Saúde Pública 2010; 26 (9); 1865-6.

6. Nolte E, Mckee M. Caring for people with chronic conditions: a health system perspective. New York: Open University Press; 2008.

7. Malta DC, Merhy EE. O percurso da linha do cuidado sob a perspectiva das doenças crônicas não transmissíveis. Interface (Botucatu). 2010; 14(34): 593-605.

8. Schmidt MI, Duncan BB, Hoffmann JF, Moura L, Malta DC, Carvalho RMSV. Prevalência de diabetes e hipertensão no Brasil baseada em inquérito de morbidade auto-referida, Brasil, 2006. Rev Saúde Pública 2009; 43(2): 74-82.

9. Aciole GG. Público e privado na política de assistência à saúde no Brasil: atores, processos e trajetória. Ciênc Saúde Coletiva 2008; 13(5): 1687-8.

10. Szwarcwald CL, Mendonça MHM, Andrade CLT. Indicadores de atenção básica em quatro municípios do estado do Rio de Janeiro 2005: resultados de inquérito domiciliar de base populacional. Ciênc Saúde Coletiva 2006; 11(3): 643-55.

11. Brasil. Instituto Brasileiro de Geografia e Estatística. Pesquisa Nacional por Amostra de Domicílios: Um panorama da saúde no Brasil. Acesso e utilização dos serviços, condições de saúde e fatores de risco e proteção à saúde 2008. Rio de Janeiro; 2010.

12. Malta DC, Moura EC, Oliveira M, Santos FP dos. Usuários de planos de saúde: morbidade referida e uso de exames preventivos, por inquérito telefônico, Brasil, 2008. Cad Saúde Pública 2011; 27(1): 57-66.

13. Agência Nacional de Saúde Suplementar. Caderno de Informação da Saúde Suplementar: beneficiários, operadoras e planos. Rio de Janeiro; 2010.

14. Brasil. Secretaria de Vigilância em Saúde. Secretaria de Gestão Estratégica e Participativa. Vigitel 2009: vigilância de fatores de risco e proteção para doenças crônicas por inquérito telefônico. Brasília: Ministério da Saúde; 2010.

15. Bussab WO, Morettin PA. Estatística básica. São Paulo: Saraiva; 2010.

16. Brasil. Instituto Brasileiro de Geografia e Estatística. Pesquisa Nacional por Amostra de Domicílios: um panorama da saúde no Brasil. Acesso e utilização dos serviços, condições de saúde e fatores de risco e proteção à saúde 1998. Rio de Janeiro; 2000.
17. Malta DC, Cecílio LCO, Merhy EL, Franco TB, Jorge AO, Costa MA. Perspectivas da regulação na saúde suplementar diante dos modelos assistenciais. Ciênc Saúde Coletiva 2004; 9(2): 433-44.

18. Ribeiro MCSA, Barata RB, Almeida MF, Silva ZP. Perfil sociodemográfico e padrão de utilização de serviços de saúde para usuários e não usuários do SUS - PNAD 2003. Ciênc Saúde Coletiva 2006; 11(4): 1011-22.

19. Lima-Costa MF, Peixoto SV, Firmo JOA. Validade da hipertensão arterial auto-referida e seus determinantes (Projeto Bambuí). Rev Saúde Públ 2004; 38(5): 637-42.

20. Ferreira SRG, Moura EC, Malta DC, Sarno F. Frequência de hipertensão arterial e fatores associados: Brasil, 2006. Rev Saúde Pública 2009; 43(2): 98-106.

21. Lessa I. A epidemiologia da hipertensão arterial sistêmica e da insuficiência cardíaca no Brasil. Rev Bras Hiperten 2001; 8(4): 383-92.

22. Malta DC, Jorge AO. O mercado de saúde suplementar e análise dos dados das operadoras selecionadas. In: BRASIL. Duas Faces da Moeda: Microrregulação e Modelos Assistenciais na Saúde Suplementar/ANS. Rio de Janeiro: Ministério da Saúde; 2005. p. 37-60.

23. Brasil. Secretaria de Atenção à Saúde. Hipertensão Arterial Sistêmica para o Sistema Único de Saúde. Brasília: Ministério da Saúde; 2006.

24. Passos VM, Assis TD, Barreo SM. Hipertensão arterial no Brasil: estimativa de prevalência a partir de estudos de base populacional. Epidemiol Serv Saúde 2006; 15(1): 35-45.

25. Toledo MM, Rodrigues SC, Chiesa AM. Educação em saúde no enfrentamento da hipertensão arterial: uma nova ótica para um velho problema. Texto e Contexto Enferm 2007; 16(2): 233-8.

26. Dias VP, Siveira AT, Witt RR. Educação em saúde: o trabalho de grupos em Atenção Primária. Rev APS 2009; 12(2): 221-7.

27. Alves VS. Um modelo de educação em saúde para o programa de saúde da família: pela integralidade da atenção e reorientação do modelo assistencial. Interface - Comunic, Saúde, Educ 2005; 9(16): 39-52.

28. Olmos RD, Benseñor IM. Dietas e hipertensão arterial: intersalt e estudo DASH. Rev Bras Hipertens 2001; 8(2): 221-4.

29. Monteiro MF, Sobral-Filho DC. Exercício físico e o controle da pressão arterial. Rev Bras Med Esporte 2004; 10(6): 513-9.

30. Palota L. Adesão ao tratamento da hipertensão arterial: estudo entre usuários cadastrados no centro de saúde de um município do interior paulista [dissertação de mestrado]. Ribeirão Preto: Escola de Enfermagem de Ribeirão Preto, USP; 2010. 
31. Lewington S; Clarke R, Qizibash N, Peto R, Collins R. Age-specific relevance of usual blood pressure to vascular mortality: a meta-analysis of individual data for one million adults in 61 prospective studies. Lancet 2002; 360(9349): 1903-13.

32. Bernal R, Silva NN. Cobertura de linhas telefônicas residenciais e vícios potenciais em estudos epidemiológicos. Rev Saude Publica 2009;43(3): 421-6.

33. Ferreira AD, César CC, Malta DC, Andrade ACS, Ramos CGC, Proietti FA, et al. Validade de estimativas obtidas por inquérito telefônico: comparação entre VIGITEL 2008 e Inquérito Saúde em Beagá. Rev Bras Epidemiol 2011; 14(1): 16-30.

34. Mokdad AH, Remington PL. Measuring health behaviors in populations. Prev Chronic Dis 2010; 7(4): A75.

Received on: 02/18/2014

Final version presented on: 04/14/2014

Accepted on: 04/14/2014 